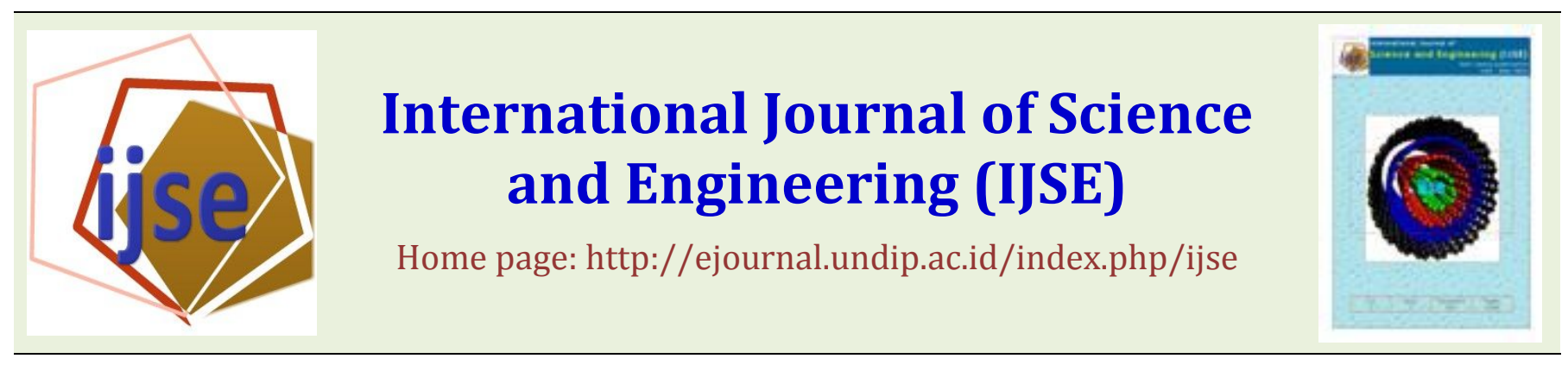

\title{
Result of Six Local Upland Rice Cultivars of East Kalimantan at Different Plant Spacing
}

\author{
Rusdiansyah11), Yazid Ismi Intara1) and Budi Indra Setiawan'2) \\ 1)Agro-technology Departement of Agricultural Faculty, Mulawarman University, Samarinda, East Kalimantan. \\ 2)Agricultural Enginering Department, IPB (Bogor University), Bogor, West Java
}

Email: izmi_6@yahoo.com

\begin{abstract}
The objective of this research was to evaluate the response of six upland rice cultivars from East Kalimantan over different plant spacing. The experiment was conducted at Kutai Kartanegara district in East Kalimantan, Indonesia. The experimental design used was the factorial experiment in Randomized Completely Block Design (RCDB) with three replications. The first factor was six upland rice cultivars of East Kalimantan, i.e.: v1 (Mayas Pancing), v2 (Gedagai), v3 (Bogor Putih), v4 (Mayas Putih), v5 (Serai) and v6 (Kunyit). The second factor was plant spacing i.e.: $j_{1}(20 \times 20 \mathrm{~cm})$ and $j_{2}(30 \times 30 \mathrm{~cm})$. The results showed that among the six cultivars, Gedagai, Bogor Putih and Kunyit produced higher yield than other varieties. Gedagai and Bogor Putih cultivars produced higher yield of 2.99 ton ha-1 at plant spacing $20 \times 20 \mathrm{~cm}$, whereas Kunyit produced higher yield of 2.66 ton ha ${ }^{-1}$ at plant spacing $30 \times 30 \mathrm{~cm}$. The agronomic characters showed that plant height of the six cultivars differed significantly at harvest time. In addition, highly significant differences of harvest time were observed of the six cultivars.
\end{abstract}

Keywords - Upland rice; plant spacing; yield potency; local cultivar

Submission: December 19, 2012

Corrected : March 3, 2013

Accepted: March 11, 2013

Doi: http://dx.doi.org/10.12777/ijse.4.2.2013.66-68

\section{INTRODUCTION}

The potential dry farming (un-irrigated agricultural field) area in Indonesia is large at around 11 million ha compared to that of 8.5 million ha wetland rice field. With such potential, it is necessary to develop innovations for dry farming rice cultivation as an effort to fulfill national rice demand and to return food self-sufficiency especially rice (Pasandaran et al., 2005).

East Kalimantan has the potential of land resources, among others: wetland agriculture, dry farming agriculture, peat lands, and coastal areas. The potential of land resources has stimulated the development and technology application to take advantage of the existing opportunities.

Upland rice is one of prospective commodities for further research (Chang and De Datta. 1975). To date, rice is mostly cultivated in wetland rice field hence upland rice development is potential for dry farming utilization. In present time, Indonesia directs its national rice program at rice production in dry farming outside Java (Krisnamurthi, 2006).

One of the efforts of dry farming utilization in East Kalimantan is to make use of local upland rice cultivars due to their good adaptation ability against less advantage environmental condition. Local upland rice cultivars can serve as a regional asset that can be relied upon in the future as income source. The cultivars are very efficient in fertilizer use and resistant to various diseases (Setyowati, 2007). In addition, dry farming farmers prefer planting local rice cultivars due to low input, good taste of rice and relatively resistant to blast disease (Bonman, 1992).

Based on the above mentioned conditions, several local upland rice cultivars originated from East Kalimantan have been examined to see their agronomic characters respond to different plant spacing.

\section{MATERIALS AND METHODS}

The research was conducted in Desa Karang Tunggal in Tenggarong Seberang sub-district, Kutai Kartanegara district. Six local upland rice cultivars (Mayas Pancing, Gedagai, White Bogor, White Mayas, Serai, Kunyit) were used. Urea Fertilizer, KCL, SP-36, fungicide, and pesticide were applied.

The experimental design used was the factorial experiment involving two factors in Randomized Completely Block Design (RCDB) with three replications. The first factor was cultivars (v) i.e.: Mayas Pancing as $v_{1}$; Gedagai as $\mathrm{v}_{2}$; Bogor Putih as $\mathrm{v}_{3}$; Mayas Putih as $\mathrm{v}_{4}$; Serai 
as $\mathrm{V}_{5}$; and Kunyit as $\mathrm{V}_{6}$. The second factor was plant spacing (j) i.e.: $\mathrm{j}_{1}$ as plant spacing of $20 \times 20 \mathrm{~cm}$ and $\mathrm{j}_{2}$ as plant spacing of $30 \times 30 \mathrm{~cm}$.

\section{RESULTS AND DISCUSSIONS}

The effort related to dry farming utilization in East Kalimantan is by using local upland rice cultivars because they have good adaptability to less advantage environmental condition. The cultivars are regional asset that can be relied upon in the future as a potential regional income source.

Generally, local upland rice cultivars are available widely specific to villages and hereditary cultivated by traditional communities. Therefore, the cultivars have adapted to the specific environment. However, to present, most of local upland rice cultivars have not been identified and selected for potential use.
The statistical analysis (ANOVA) showed that cultivar influence on all observed parameters only gave significant effect on plant height and total shoot number per clump on the 45 days after planting (DAP), while on the 90 DAP, total shoot per clump, number of spikelet per clump, total filled spikelet per clump, weight of 1000 grains, and potential result showed insignificant influence (Table 1).

The insignificant difference in plant height either on 45 DAP or 90 DAP was probably due to environmental factors (Fig.1). On the 45 DAP, the plant is still in its vegetative growth phase hence the plant organs are not yet optimal. The environmental condition that supports plant growth due to competition between plants is still very small in line spacing. Plant height at 90 DAP showed insignificant difference caused by environmental change from the rain season to dry season. The condition made plant spacing treatment does not show direct influence on plant growth.

Table 1. Potential result of six upland rice cultivars from East Kalimantan in different spacing

\begin{tabular}{|c|c|c|c|c|c|c|c|c|}
\hline \multirow[t]{2}{*}{ Treatment } & \multicolumn{2}{|c|}{ Plants height $(\mathrm{cm})$} & \multirow{2}{*}{$\begin{array}{l}\text { Total } \\
\text { shoot } \\
\text { number } \\
\text { (stem) }\end{array}$} & \multirow{2}{*}{$\begin{array}{l}\text { Productive } \\
\text { shoot } \\
\text { number } \\
\text { (stem) }\end{array}$} & \multirow{2}{*}{$\begin{array}{l}\text { Spikelet } \\
\text { number } \\
\text { (grain) }\end{array}$} & \multirow{2}{*}{$\begin{array}{l}\text { Filled } \\
\text { seed } \\
\text { number } \\
\text { (grain) }\end{array}$} & \multirow{2}{*}{$\begin{array}{l}\text { Weight } \\
\text { of } 1000 \\
\text { grains } \\
(\mathrm{g})\end{array}$} & \multirow{2}{*}{$\begin{array}{l}\text { Potential } \\
\text { result } \\
\left(\text { ton } \mathrm{ha}^{-1}\right)\end{array}$} \\
\hline & $\begin{array}{c}45 \\
\text { (DAP) }\end{array}$ & $\begin{array}{c}90 \\
(\mathrm{DAP})\end{array}$ & & & & & & \\
\hline Cultivar & $*$ & ns & $*$ & ns & ns & ns & ns & ns \\
\hline $\mathrm{v}_{1}$ & 79.35 & 117.12 & 9.25 & 5.29 & 1086.35 & 504.57 & 21.03 & 1.42 \\
\hline $\mathrm{v}_{2}$ & 87.11 & 116.22 & 7.19 & 3.86 & 910.54 & 528.66 & $25, .19$ & 2.16 \\
\hline$v_{3}$ & 70.85 & 112.90 & 6.42 & 4.09 & 1127.48 & 665.83 & 26.36 & 1.60 \\
\hline $\mathrm{v}_{4}$ & 82.91 & 123.33 & 7.35 & 4,80 & 1101.22 & 656.77 & 28.74 & 1.30 \\
\hline $\mathrm{v}_{5}$ & 81.53 & 125.10 & 7.63 & 5.14 & 1172.34 & 625.10 & 26.35 & 1.03 \\
\hline $\mathrm{v}_{6}$ & 93.97 & 123.20 & 5.12 & 3.08 & 857.34 & 520.28 & 26.38 & 2.10 \\
\hline Plant spacing & $\mathrm{ns}$ & $\mathrm{ns}$ & $* *$ & $* *$ & $* *$ & $*$ & $*$ & ns \\
\hline $\mathrm{j}_{1}$ & 82.57 & 115.52 & $5.80^{b}$ & $3.33^{b}$ & $751.55^{b}$ & $404.63^{\mathrm{a}}$ & $24.23^{b}$ & 1.73 \\
\hline $\mathrm{j}_{2}$ & 82.60 & 123.77 & $8.52^{a}$ & $5.43^{\mathrm{a}}$ & $1333.34^{\mathrm{a}}$ & $762.43^{b}$ & $28.87^{\mathrm{a}}$ & 1.19 \\
\hline Interaction & ns & ns & $\mathrm{ns}$ & ns & $*$ & ns & ns & $\mathrm{ns}$ \\
\hline $\mathrm{v}_{1} \mathrm{j}_{1}$ & 72.98 & 113.81 & 7.59 & 4.22 & 1070.06 & 504.42 & 20.01 & 1.55 \\
\hline $\mathrm{v}_{2} \mathrm{j}_{1}$ & 88.40 & 112.31 & 5.26 & 3.64 & 917.43 & 590.97 & 25.19 & 2.99 \\
\hline$v_{3} j_{1}$ & 77.44 & 117.77 & 5.83 & 3.66 & 976.02 & 652.23 & 25.20 & 2.06 \\
\hline $\mathrm{v}_{4} \mathrm{j}_{1}$ & 80.49 & 118.13 & 6.55 & 2.84 & 534.55 & 168.58 & 25.87 & 1.13 \\
\hline$v_{5} j_{1}$ & 85.40 & 117.59 & 5.56 & 3.36 & 513.49 & 166.11 & 24.35 & 1.11 \\
\hline $\mathrm{v}_{6} \mathrm{j}_{1}$ & 90.76 & 113.48 & 3.99 & 2.25 & 497.73 & 245.46 & 24.76 & 1.59 \\
\hline $\mathrm{v}_{1} \mathrm{j}_{2}$ & 85.71 & 120.42 & 7.59 & 6.36 & 1102.64 & 504.72 & 22.05 & 1.29 \\
\hline $\mathrm{v}_{2} \mathrm{j}_{2}$ & 85.81 & 120.13 & 5.26 & 4.09 & 903.64 & 466.38 & 26.94 & 1.33 \\
\hline $\mathrm{v}_{3} \mathrm{j}_{2}$ & 64.25 & 108.03 & 5.83 & 4.53 & 1278.95 & 679.42 & 27.51 & 1.14 \\
\hline $\mathrm{v}_{4} \mathrm{j}_{2}$ & 85.32 & 128.52 & 6.55 & 6.76 & 1667.89 & 1044.96 & 31.61 & 1.47 \\
\hline$v_{5} j_{2}$ & 77.66 & 132.58 & 5.56 & 6.93 & 1831.18 & 1084.02 & 28.34 & 0.94 \\
\hline $\mathrm{v}_{6} \mathrm{j}_{2}$ & 96.83 & 132.91 & 3.99 & 3.92 & 1216.94 & 795.11 & 28.01 & 2.61 \\
\hline
\end{tabular}

Note: Figures followed by the same letter are not significantly different at $5 \%$ Least Significance Difference test

Significant difference in total shoot number per clump, productive shoot number per clump, number of spikelet per clump, was probably due to environmental factors. Limited water content in soil due to the lack of rainfall can cause plants experiencing water shortages and soil nutrient uptake disrupted. Competition between plants can be caused by tight plant spacing, especially in water absorption compared to the less tight plant spacing. Efficiency of light use, soil nutrient and water can be influenced by the arrangement of plant spacing that eventually influence growth and potential result. Plant competition caused resisted of plant height, total shoot number, spikelet number and potential yield result.

Based on potential result, plant spacing of $20 \times 20 \mathrm{~cm}$ gives better result compared to that of plant spacing of 30 x $30 \mathrm{~cm}$. Interaction between cultivar and plant spacing ( $\mathrm{v}$ $x \mathrm{j}$ ) has insignificant influence towards most of observed parameters. Significant difference was not visible because each treatment had no mutual connection that influenced growth and yield result. Each treatment gave the influence independently. In accordance with Steel and Torrie (1991), if interaction happened between one treatment to another was insignificantly difference, then it can be concluded that these factors acting independently to one another.

Although there was insignificantly interaction, it was shown that Gedagai cultivar $\left(\mathrm{v}_{2}\right)$ and Bogor Putih cultivar $\left(\mathrm{v}_{3}\right)$ gave high result in plant spacing of $20 \times 20 \mathrm{~cm}$ and yielded 2.99 ton $\mathrm{ha}^{-1}$ and 2.06 ton ha-1 respectively, while Kunyit cultivar $\left(\mathrm{v}_{6}\right)$ gave high result in plant spacing of 30 $\mathrm{x} 30 \mathrm{~cm}$ that was 2.61 ton $\mathrm{ha}^{-1}$. 

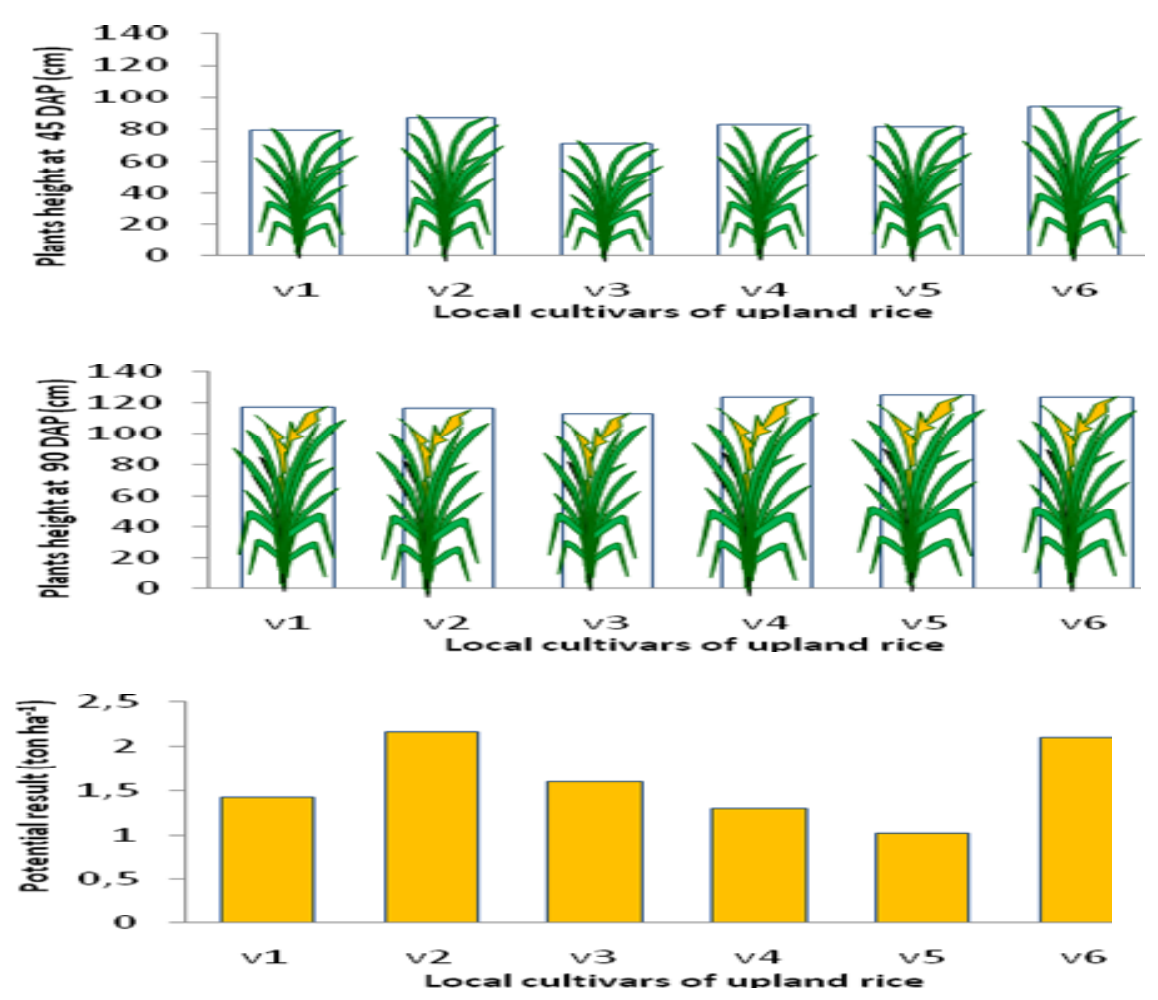

Figure 1. Graph from result of research data summary; a) plants hight when measurement at $45 \mathrm{DAP}$, b) plants hight when measurement at $90 \mathrm{DAP}$, and c) result potency six local cultivars up land paddy (ton ha-1)

\section{CONCLUSIONS}

1. Based on potential results, it was found that three cultivars that was Gedagai, Bogor Putih and Kunyit give high result.

2. Gedagai and Bogor Putih Cultivars give high result in treatment of plant spacing of $20 \times 20 \mathrm{~cm}$ and yielded 2.99 ton ha $^{-1}$ and 2.06 ton ha ${ }^{-1}$ respectively, while Kunyit cultivar gives high result in plant spacing of $30 \mathrm{x}$ $30 \mathrm{~cm}$ that was 2.61 ton ha-1.

3. Upland rice production will increase with the use of technology input such as fertilizing, the use of high potential cultivars with the correct spacing arrangement, good water distribution system and soil tillage.

\section{REFERENCES}

[1]. Bonman, J.M. 1992. Durable Resistance to Rice Blast DiseaseEnvironmental Influence. Euphytica 63:115-123.

[2]. Chang, T. T. and S. K. De Datta. 1975. Agronomic traits needed in upland rice varieties. In: Major Research in Upland Rice: 93-100. IRRI, Los Banos. Philippines.

[3]. Krisnamurthi, B. 2006. Agriculture Revitalization and the challenges for rice industry in Indonesia. In: Sumarno,Suparyono, A. F. Fagi and M. O. Adnyana. Rice Industry, Culture and Environtment, Book 1. Proceedings of the International Rice Conference September 12-14 2005.ICCR. ICFORD. IAARD. Bali. p. 55-20

[4]. Pasandaran E. P Simatupang and A.M Fagi. 2006. Perspective of rice production in Indonesia. In: Sumarno,Suparyono, A. F. Fagi and M. O. Adnyana. Rice Industry,Culture, and Environtment, Book 1. Proceedings of the International Rice Conference September 12-14 2005.ICCR. ICFORD. IAARD. Bali. p. 55-64

[5]. Setiowati, E., Rudarmono and Rusdiansyah. 2007. Evaluation of Yield Potency of Local Cultivar Upland Rice (Oryza sativa L.) from Sembakung of Nunukan District. Jurnal Budidaya Pertanian: 13 (2): 73-79

[6]. Stell, R. G. D dan J. H. Torrie. 1991. Principles and Of Statistic. Gramedia, Jakarta 